\title{
Occurrence of arrhenotoky and thelytoky in a parasitic wasp Venturia canescens (Hymenoptera: Ichneumonidae): Effect of endosymbionts or existence of two distinct reproductive modes?
}

\author{
VINCENT FORAY ${ }^{1,2}$, HélĖNe HENRI ${ }^{1}$, Sonia MARTINEZ ${ }^{1}$, Patricia GIBERT ${ }^{1}$ and EMmANUEl DESOUHANT ${ }^{1}$ \\ ${ }^{1}$ Université Lyon 1, Laboratoire de Biométrie et Biologie Evolutive, F-69000 Lyon \& CNRS, UMR5558, F-69622 Villeurbanne, \\ France \\ ${ }^{2}$ Earth and Life Institute, Biodiversity Research Centre, Catholic University of Louvain, Croix du Sud 4-5, B-1348 \\ Louvain-la-Neuve, Belgium; e-mail: vincent.foray@uclouvain.be
}

Key words. Hymenoptera, Ichneumonidae, Venturia canescens, reproductive parasite, thelytokous parthenogenesis, sex evolution

\begin{abstract}
Endosymbiotic organisms are known to manipulate the reproductive biology of their hosts. Incomplete prevalence of endosymbiont inducing thelytokous parthenogenesis results in the coexistence of sexual and asexual individuals, and could account for the maintenance of sexual reproduction in certain populations or species. In the parasitoid Venturia canescens, arrhenotokous ("sexual") and thelytokous ("asexual") individuals occur sympatrically. We aimed to determine whether endosymbionts are implicated in the thelytoky of $V$. canescens. After screening females of the two reproductive modes for several reproductive parasites: bacteria (Wolbachia, Rickettsia, Bacteroidetes, Spiroplasma, Arsenophonus) and Microsporidia, we concluded that thelytoky in $V$. canescens is not induced by any of these parasites and confirmed its suitability as a biological model for solving the evolutionary enigma of the maintenance of sexual reproduction.
\end{abstract}

\section{INTRODUCTION}

Often tackled but never resolved, the question of how sexual reproduction is maintained in eukaryotes remains one of the most important enigmas in evolutionary biology (Stearns, 1990; Otto, 2009). A key point of contention is in the imbalance between the obvious demographic and genetic costs of sex (Maynard-Smith, 1978) vs the lack of demonstrated short term advantages. Niche differentiation, highlighted by environmental dependent differences in fitness of sexual and asexual forms, seems to be a fruitful avenue of investigation to resolve this issue (Amat et al., 2006, 2009; Tobler \& Schlupp, 2010). In order to evaluate this hypothesis, it is necessary to compare closely related sexual and asexual species or individuals of the same species that occur sympatrically.

However, the hallmarks of such ecological situations can be confused with altered genomic constitutions such as hybridization and polyploidization or be associated with parthenogenesis-inducing microbes. Particularly for arthropods, the presence of reproductive parasites, i.e. endosymbiotic organisms manipulating the reproduction of their hosts, was widely documented during the last decades, initially with Wolbachia (Stouthamer et al., 1990). Recently, the list of bacterial endosymbionts has grown with the addition of Cardinium (Zchori-Fein et al., 2001), Rickettsia (Hagimori et al., 2006), Arsenophonus (Gherna et al., 1991) and Spiroplasma (Hurst et al., 1999). Microsporidia are also capable of manipulating reproduction in species of amphipod and mosquito (Dunn \& Smith, 2001). These maternally transmitted parasites manipulate their host's reproduction in order to enhance their rate of transmission in host populations in different ways: cytoplasmic incompatibility, feminisation of genetic males, male killing and induction of thelytokous parthenogenesis (Turelli \& Hoffmann, 1995; Hogg et al., 2002; Bourtzis \& Miller, 2003; Werren et al., 2008; Saridaki \& Bourtzis, 2010).

Coexistence of sexual and asexual individuals within a population may be due to incomplete prevalence of organisms inducing parthenogenesis. Stouthamer et al. (2001) proposed three processes to explain an intermediate proportion of infected and non-infected individuals in a population: (i) inefficient transmission of the parasite, (ii) existence of suppressor genes in hosts and (iii) presence of male-biasing sex-ratio distorters, as in Trichogramma kaykai (Hymenoptera: Trichogrammatidae). In conjunction with these factors, costs of carrying endosymbiotic parasites may influence the level of prevalence. Such costs may be expressed in terms of higher mortality, lower fecundity and reduced locomotor activity of the hosts (Fleury et al., 2000).

In the hymenopteran parasitoid, Venturia canescens Gravenhorst (Hymenoptera: Ichneumonidae), the natural co-occurrence of wasps with two different modes of reproduction, arrhenotoky (called "sexual") and thelytoky ("asexual"), has been interpreted as evidence for two coexisting modes of reproduction (Schneider et al., 2002; Amat et al., 2006; Thiel et al., 2006; Pelosse et al., 2007) rather than the induction of thelytokous parthenogenesis. However, the prevalences of reproductive parasites in $V$. canescens has to be clarified because Cook \& Butcher (1999) highlighted the presence of Wolbachia, whereas Mateo-Leach et al. (2009), who used antibiotic treatment and PCR screening with prokaryotic primers, concluded 
that prokaryotes are unlikely to be implicated in the thelytokous parthenogenesis in $V$. canescens. In addition to the lack of congruence between these results, we know that PCR screening with prokaryotic primers and antibiotic treatment are sensitive to the density and diversity of bacteria, potentially leading to false negative results (Suzuki \& Giovannoni, 1996). Thus, complementary analyses are necessary before reaching a conclusion on the determinism of the thelytoky in $V$. canescens. Here, we aim to determine whether thelytoky in $V$. canescens is correlated with the presence of endosymbiotic bacteria, using specific and generic primers of the bacteria that manipulate reproduction. In addition, we test for the first time whether the presence of Microsporidia is implicated in thelytoky in $V$. canescens. Our study should indicate whether the co-occurrence of females producing only female offspring (thelytoky) with those producing males and females (arrhenotoky) is indicative of the cooccurrence of uninfected individuals with two different reproductive modes, or a result of the co-occurrence of parasitized and un-parasitized arrhenotokous individuals.

\section{MATERIALS AND METHODS}

\section{Biological material}

Venturia canescens is a solitary koinobiont endoparasitoid of mainly Pyralidae larvae. It possesses a haplodiploid sex determination system: haploid individuals from unfertilised eggs are males whereas diploid individuals from fertilised eggs are females. Arrhenotokous parthenogenesis contrasts with thelytokous parthenogenesis because under thelytoky diploid females develop from unfertilised eggs and no males are produced. Arrhenotokous strains of $V$. canescens were discovered a few years ago occurring naturally, with the two reproductive modes occurring sympatrically (Schneider et al., 2002). Gene flow occurs between arrhenotokous and thelytokous populations and it is hypothesized that thelytokous individuals originate from arrhenotokous ones (Schneider et al., 2002, 2003; Mateo-Leach et al., 2012), indicating that the two reproductive modes belong to the same species. In our experiment, we used arrhenotokous and thelytokous strains of $V$. canescens established from individuals collected near Valence (France, $44^{\circ} 58^{\prime} 34^{\prime \prime} \mathrm{N}, 4^{\circ} 55^{\prime} 6^{\prime \prime} \mathrm{E}$ ) in 2007 and 2008. Individuals of each of these reproductive modes were reared separately in the laboratory with Ephestia kuehniella (Lepidoptera: Pyralidae) as the host and in a controlled environment $\left(25 \pm 1{ }^{\circ} \mathrm{C}, 70 \pm 5 \% \mathrm{RH}\right.$ and $\left.12 \mathrm{~L}: 12 \mathrm{D}\right)$.

\section{DNA extraction and screening}

If thelytokous parthenogenesis is induced by an endosymbiotic organism, then the expectation is that the analyses will reveal the presence of at least one species of reproductive parasite in all the thelytokous females and none in arrhenotokous ones. Consequently, the sample sizes for molecular analyses do not need to be large. Further, if a bacterium or a microsporidium induces thelytoky in $V$. canescens, we should find it in the ovaries of all thelytokous wasps. For each reproductive mode, analyses were performed on five nymphal females in both years sampled. They were carefully extracted from cocoons by dissection before the imaginal moult. Further, analyses were performed on three pools of gonads from wasps sampled in 2008 . Each pool consists of ten ovaries and oviducts of adult wasps of the same reproductive mode. Ovaries and oviducts were dissected in $10 \mu \mathrm{l}$ of ethanol $(70 \%)$. Pools of gonads were used to test for the presence of low numbers of reproductive parasites. Nymphs and gonads were then kept individually at $-20^{\circ} \mathrm{C}$.

DNA extraction and purification were performed using the

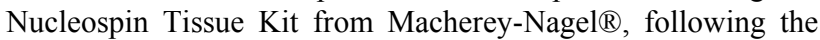
manufacturer instructions (volume of elution $=100 \mu \mathrm{l}$ ). The DNA quality was systematically tested using polymerase chain reaction (PCR) amplification of a region present in thelytokous and arrhenotokous $V$. canescens, which codes for a VLP (VirusLike Partical) (Theopold et al., 1994), using primers listed in Table 1. We used specific primers (Table 1) to investigate the presence of six taxa of endosymbiotic bacteria: Wolbachia, Rickettsia, Bacteroidetes, Cardinium, Spiroplasma and Arsenophonus. We also performed PCR amplifications of a conserved region of the Prokaryote $16 \mathrm{~S}$ rDNA and of a conserved region of the Microsporidia 16S rDNA, with respectively two sets of primers in order to limit potential bias of amplification (Suzuki \& Giovannoni, 1996; Table 1). For all analyses, we included an appropriate positive control (Table 1). Positive amplifications were then directly sequenced in order to determine the nature of the organism present.

PCRs were performed in a final volume of $25 \mu \mathrm{l}$ containing $200 \mu \mathrm{M}$ dNTPs, $200 \mathrm{nM}$ of each primer, $1.5 \mathrm{mM}$ of $\mathrm{MgCl}_{2}, 1 \mathrm{X}$ Taq buffer and $0.5 \mathrm{U}$ of taq polymerase (EuroblueTaq, Eurobio, France) and $2 \mu \mathrm{l}$ of the DNA template. PCRs were performed under the following conditions: initial denaturation at $95^{\circ} \mathrm{C}$ for 2 min, 35 cycles of denaturation $\left(94^{\circ} \mathrm{C}, 30 \mathrm{~s}\right.$ ), annealing (50 to $63^{\circ} \mathrm{C}$, depending on primers, $\left.30 \mathrm{~s}\right)$, extension $\left(72^{\circ} \mathrm{C}, 1 \mathrm{~min}\right)$ and a final extension at $72^{\circ} \mathrm{C}$ for $5 \mathrm{~min}$. The PCR products were then visualized using agarose gel electrophoresis.

\section{RESULTS AND DISCUSSION}

Among the thelytokous and arrhenotokous females of $V$. canescens that were screened, all analyses on pools of gonads produced negative results and positive results were obtained with Wolbachia primers (FbpA and 16S) and prokaryotic primers (16S) for two and five thelytokous females, respectively. The sequencing of the two positive samples for Wolbachia, using forward (FbpA-F and Wolb-F) and reverse (FbpA-R and Wolb-R) primers (Biofidal, Villeurbanne, France), revealed an unequivocal single sequence in both senses, for each pair of primers, respectively (access numbers: JX399797 and JX399793). BLAST analysis of the sequences showed that the Wolbachia belong to clade A, which is one of the most common infecting Arthropods (Werren \& Windsor, 2000). Two positive samples with prokaryotic primers were also sequenced, using both forward (E8F) and reverse (1541R and 1389R) primers (Genoscreen, Lille, France), and revealed an unequivocal single sequence in both senses and for both individuals tested, given the quality of each base. BLAST analysis showed 99\% similarity with Enterococcus mundtii (GQ337033). Species of Enterococci are not recorded as reproductive parasites but are generally associated with the digestive organs of insects (Geiger et al., 2009). As Wolbachia and E. mundtii were not systematically detected in thelytokous females and never in pools of gonads, they are not implicated in the thelytoky of $V$. canescens. These positive results are not a consequence of contamination because reproductive parasites were never detected in the negative controls.

Thus, we conclude with confidence that thelytokous parthenogenesis in $V$. canescens is genetic and is not 
TABLE 1. Primers used in polymerase chain reaction (PCR) assays to detect microbes manipulating reproduction and control quality DNA. Analyses with specific and generic primers were performed respectively on nymphal females and pools of ovaries of $V$. canescens. $\mathrm{Tm}=$ annealing temperature.

\begin{tabular}{|c|c|c|c|c|c|c|}
\hline Organism (gene) & Primers & Sequence $\left(5^{\prime}-3^{\prime}\right)$ & $\mathrm{Tm}$ & Size & Positive control & Reference \\
\hline$V$. canescens $(V L P)$ & $\begin{array}{l}\text { Vcan-F } \\
\text { Vcan-R }\end{array}$ & $\begin{array}{l}\text {-CTCAATATGTGGGGTGGTGG- } \\
\text {-TCGCAGTGGCTTGTCAGAGT- }\end{array}$ & $56^{\circ} \mathrm{C}$ & $250 \mathrm{bp}$ & $V$. canescens & Theopold et al., 1994 \\
\hline \multirow{3}{*}{$\begin{array}{l}\text { Wolbachia } \\
(\text { WSP/FbpA/16S) }\end{array}$} & $\begin{array}{l}81-\mathrm{F} \\
691-\mathrm{R} \\
\end{array}$ & $\begin{array}{l}\text {-TGGTCCAATAAGTGATGAAGAAAC- } \\
\text {-AAAAATTAAACGCTACTCCA- }\end{array}$ & $52^{\circ} \mathrm{C}$ & $610 \mathrm{bp}$ & \multirow{3}{*}{$\begin{array}{l}D . \\
\text { melanogaster }\end{array}$} & \multirow{3}{*}{$\begin{array}{c}\text { Braig et al., } 1998 \\
\text { Baldo et al., } 2006 \\
\text { O’Neill et al., } 1992\end{array}$} \\
\hline & $\begin{array}{l}\text { FbpA-F } \\
\text { FbpA-R }\end{array}$ & $\begin{array}{l}\text {-CCRCCAGARAAAAYYACTATTC- } \\
\text {-TGGTCCAATAAGTGATGAAGAAAC- }\end{array}$ & $55^{\circ} \mathrm{C}$ & $509 \mathrm{bp}$ & & \\
\hline & $\begin{array}{l}\text { Wolb-F- } \\
\text { Wolb-R }\end{array}$ & $\begin{array}{l}\text {-TTGTAGCCTGCTATGGTATAACT- } \\
\text {-GAATAGGTATGATTTTCATGT- }\end{array}$ & $52^{\circ} \mathrm{C}$ & 936bp & & \\
\hline Bacteroidetes (16S) & $\begin{array}{l}\text { Ch-F } \\
\text { Ch-R }\end{array}$ & $\begin{array}{l}\text {-TACTGTAAGAATAAGCACGGC- } \\
\text {-GTGGATCACTTAACGCTTTCG- }\end{array}$ & $57^{\circ} \mathrm{C}$ & $900 \mathrm{bp}$ & Bemisia tabaci & $\begin{array}{l}\text { Zchori-Fein \& } \\
\text { Perlman, } 2004\end{array}$ \\
\hline Cardinium (16S) & $\begin{array}{l}\text { CLO-F } \\
\text { CLO-R }\end{array}$ & $\begin{array}{l}\text {-GGAACCTTACCTGGGCTAGAATGTATT- } \\
\text {-GCCACTGTCTTCAAGCTCTACCAAC- } \\
\end{array}$ & $56^{\circ} \mathrm{C}$ & $500 \mathrm{bp}$ & Bemisia tabaci & Gotoh et al., 2007 \\
\hline Rickettsia (16S) & $\begin{array}{l}\mathrm{Rb}-\mathrm{F} \\
\mathrm{Rb}-\mathrm{R}\end{array}$ & $\begin{array}{l}\text {-GCTCAGAACGAACGCTATC- } \\
\text {-GAAGGAAAGCATCTCTGC- }\end{array}$ & $56^{\circ} \mathrm{C}$ & $900 \mathrm{bp}$ & Bemisia tabaci & Gottlieb et al., 2006 \\
\hline Spiroplasma (16S) & $\begin{array}{l}\text { Spixo-F } \\
\text { Spixo-R }\end{array}$ & $\begin{array}{l}\text {-TTAGGGGCTCAACCCCTAACC- } \\
\text {-TCTGGCATTGCCAACTCTC- }\end{array}$ & $52^{\circ} \mathrm{C}$ & $810 b p$ & $\begin{array}{l}\text { Zygiella } \\
x \text {-notata }\end{array}$ & Duron et al., 2008 \\
\hline Arsenophonus (23S) & $\begin{array}{l}\text { Ars23s-F } \\
\text { Ars23s-R }\end{array}$ & $\begin{array}{l}\text {-CGTTTGATGAATTCATAGTCAAA- } \\
\text {-GGTCCTCCAGTTAGTGTTACCCAAC- }\end{array}$ & $52^{\circ} \mathrm{C}$ & $650 \mathrm{bp}$ & $\begin{array}{l}\text { Omatissus } \\
\text { lybicus }\end{array}$ & Thao \& Baumann, 2004 \\
\hline \multirow{2}{*}{ Microsporidia (16S) } & $\begin{array}{c}\mathrm{V} 1-\mathrm{F} \\
1492-\mathrm{R}\end{array}$ & $\begin{array}{l}\text {-CACCAGGTTGATTCT- } \\
\text {-GGTTACCTTGTTACGACTT- }\end{array}$ & \multicolumn{2}{|c|}{$57^{\circ} \mathrm{C} 1300 \mathrm{bp}$} & \multirow{2}{*}{ C. elegans } & \multirow{2}{*}{$\begin{array}{c}\text { Weiss et al., } 1994 \\
\text { Weiss \& Vossbrinck, } \\
1998 \\
\text { Baker et al., } 1995\end{array}$} \\
\hline & $\begin{array}{l}\mathrm{V} 1-\mathrm{F} \\
530-\mathrm{R}\end{array}$ & $\begin{array}{l}\text {-CACCAGGTTGATTCT- } \\
\text {-CCGCGGCTGCTGGCAC- }\end{array}$ & $63^{\circ} \mathrm{C}$ & $450 \mathrm{bp}$ & & \\
\hline \multirow{2}{*}{ Procaryotes (16S) } & $\begin{array}{c}\mathrm{E} 8-\mathrm{F} \\
1541-\mathrm{R}\end{array}$ & $\begin{array}{l}\text {-AGAGTTTGATCATGGCTCAG- } \\
\text {-AAGGAGGTGATCCANCCRCA- }\end{array}$ & $55^{\circ} \mathrm{C}$ & $1500 \mathrm{bp}$ & \multirow{2}{*}{$\begin{array}{c}D . \\
\text { melanogaster }\end{array}$} & \multirow{2}{*}{$\begin{array}{c}\text { Reysenbach et al., } 1994 \\
\text { Suzuki \& Giovannoni, } \\
1996\end{array}$} \\
\hline & $\begin{array}{c}\mathrm{E} 8-\mathrm{F} \\
1389-\mathrm{R}\end{array}$ & $\begin{array}{l}\text {-AGAGTTTGATCATGGCTCAG- } \\
\text {-GACGGGCGGTGTGTACAA- }\end{array}$ & $55^{\circ} \mathrm{C}$ & $\overline{1400 \mathrm{bp}}$ & & \\
\hline
\end{tabular}

manipulated by reproductive parasites. However, using several specific and generic primers, we highlight that $V$. canescens is not free of bacteria. We found a low incidence of Wolbachia in $V$. canescens, as noted previously by Cook \& Butcher (1999). Additional analyses are required to locate Wolbachia and E. mundtii in wasp tissues and determine their origin and whether they affect the phenotype of $V$. canescens.

The absence of endosymbiont induced thelytoky in $V$. canescens could be explained by its sex determination mechanism, which is based on allelic composition at a single locus (sl-CSD: single locus Complementary Sex Determination) (Beukeboom, 2001). This sex determination diverges from the classical haplodiploid scheme in that diploid individuals homozygous for this locus are generally sterile or not viable males. In $V$. canescens, thelytokous parthenogenesis is automictic, leading to the maintenance of heterozygosity for loci located close to the centromere (Beukeboom \& Pijnacker, 2000). Single locus-CSD appears to constrain the infection by endosymbiont-induced thelytoky because, for instance in the case of infection with Wolbachia, thelytokous induction involves gamete duplication in order to restore the diploidy and results in completely homozygous diploid offspring (Stouthamer \& Kazmer, 1994). However, the recent discovery of Rickettsia inducing thelytoky in Neochrysocharis formosa (Hymenoptera: Eulophidae) through a cytogenetic mechanism that does not modify heterozygosity (Adachi-Hagimori et al., 2008) justifies the investigation of reproductive parasites inducing parthenogenesis in species with s1-CSD, like $V$. canescens.

Finally, our results reveal that $V$. canescens presents a clear case of coexistence in sympatry of distinct thelytokous and arrhenotokous individuals. Such a biological system, though sporadic in its occurrence among animals, is highly relevant to the investigation of one of the major unsolved problems in evolutionary biology, namely the maintenance of sexual reproduction (Otto, 2009). Recent studies on $V$. canescens appear to demonstrate niche differentiation that could explain the coexistence of the two reproductive modes, i.e. thelytokous individuals seem to be more adapted to anthropogenic and arrhenotokous individuals to natural habitats (Amat et al., 2006, 2009; Thiel et al., 2006; Pelosse et al., 2007, 2010; Foray et al., 2011). Future studies should investigate the genetic basis of thelytoky in $V$. canescens since thelytoky in the parasitoid wasp Lysiphlebus fabarum (Hymenoptera: Braconidae) is determined by a single recessive gene (Engelstädter et al., 2011; Sandrock \& Vorburger, 2011).

ACKNOWLEDGEMENTS. We are grateful to F. Débias for his help with rearing $V$. canescens and A. Dubuffet for her helpful advice on Microsporidia. We would like to thank L. Mouton and E. Kvikstad for their comments on earlier drafts of the manuscript and for their editing work. This research was supported by the French Ministry. 


\section{REFERENCES}

Adachi-Hagimori T., Miura K. \& Stouthamer R. 2008: A new cytogenetic mechanism for bacterial endosymbiont-induced parthenogenesis in Hymenoptera. - Proc. R. Soc. Lond. (B) 275: 2667-2673.

Amat I., Castelo M., Desouhant E. \& Bernstein C. 2006: The influence of temperature and host availability on the host exploitation strategies of sexual and asexual parasitic wasps of the same species. - Oecologia 148: 153-161.

Amat I., Desouhant E. \& Bernstein C. 2009: Differential use of conspecific-derived information by sexual and asexual parasitic wasps exploiting partially depleted host patches. Behav. Ecol. Sociobiol. 63: 563-572.

BaKer M.D., Vossbrinck C.R., Didier E.S., Maddox J.V. \& SHAdDUCK J.A. 1995: Small-subunit ribosomal DNA phylogeny of various microsporidia with emphasis on aids-related forms. - J. Eukaryot. Microbiol. 42: 564-570.

Baldo L., Dunning Hotopp J.C., Jolley K.A., Bordenstein S.R., Biber S.A, Choudhury R.R., Hayashi C., Maiden M.C.J., TetTELIN H. \& WerRen J.H. 2006: Multilocus sequence typing system for the endosymbiont Wolbachia pipientis. - Appl. Environ. Microbiol. 72: 7098-7110.

BеuкEвоом L.W. 2001: Single-locus complementary sex determination in the ichneumonid Venturia canescens (Gravenhorst) (Hymenoptera). - Neth. J. Zool. 51: 1-15.

Beukeboom L.W. \& Pijnacker L. 2000: Automictic parthenogenesis in the parasitoid Venturia canescens (Hymenoptera: Ichneumonidae) revisited. - Genome 43: 939-944.

Bourtzis K. \& Miller T.A. 2003: Insect Symbiosis. CRC Press, Boca Raton, FL, 347 pp.

Braig H.R., Zhou W., Dobson S.L. \& O’Neill S. 1998: Cloning and characterization of gene encoding the major surface protein of the bacterial endosymbiont Wolbachia pipientis. $-J$. Bacteriol. 180: 2373-2378.

COOK J.M. \& BUTCHER R.D.J. 1999: The transmission and effects of Wolbachia bacteria in parasitoids. - Res. Popul. Ecol. 41: 15-28.

DunN A.M. \& Smith J.E. 2001: Microsporidian life cycles and diversity: the relationship between virulence and transmission. - Microbes Infect. 3: 381-388.

Duron O., Bouchon D., Boutin S., Bellamy L., Zhou L., EngelstäDTER J. \& Hurst G.D. 2008: The diversity of reproductive parasites among arthropods: Wolbachia do not walk alone. - BMC Biology 6: 1-24.

Engelstädter J., SAndrock C. \& Vorburger C. 2011: Contagious parthenogenesis, automixis, and a sex determination meltdown. - Evolution 65: 501-511.

Fleury F., Vavre F., Ris N., Foulllet P. \& Boulétreau M. 2000: Physiological cost induced by the maternallytransmitted endosymbiont Wolbachia in the Drosophila parasitoid Leptopilina heterotoma. - Parasitology 121: 493-500.

Foray V., Gibert P. \& Desouhant E. 2011: Differential thermal performance curves in response to different habitats in the parasitoid Venturia canescens. - Naturwissenschaften 98: 683-691.

Geiger A., Fardeau M.L., Grebaut P., Vatunga G., Josénando T., Herder S., Cuny G., Truc P. \& Ollivier B. 2009: First isolation of Enterobacter, Enterococcus, and Acinetobacter spp. As inhabitants of tsetse fly (Glossina palpalis palpalis) midgut. — Infect. Genet. Evol. 9: 1364-1370.

Gherna R.L., Werren J.H., Weisburg W., Cote R., Woese C.R., Mandelco L. \& BRENner D.J. 1991: Arsenophonus nasoniae gen. nov., sp. nov., the causative agent of the son-killer trait in the parasitic wasp Nasonia vitripennis. - Int. J. Syst. Bacteriol. 41: 563-565.
Gotoh T., Noda H. \& Ito S. 2007: Cardinium symbionts cause cytoplasmic incompatibility in spider mites. - Heredity $\mathbf{9 8}$ : 13-20.

Gottlieb Y., Ghanim M., Chiel E., Gerling D., Portnoy V., Steinberg S., Tzuri G., Horowitz A.R., Belausov E., MozesDaube N., Kontsedalov S., Gershon M., Gal S., Katzir N. \& ZCHORI-FEIN E. 2006: Identification and localization of a Rickettsia sp. in Bemisia tabaci (Homoptera: Aleyrodidae). Appl. Environ. Microbiol. 72: 3646-3652.

Hagimori T., Abe Y., Date S. \& Miura K. 2006: The first finding of a Rickettsia bacterium associated with parthenogenesis induction among insects. - Curr. Microbiol. 52: 97-101.

Hogg J.C., Ironside J.E., Sharpe R.G., Hatcher M.J., Smith J.E. \& DunN A.M. 2002: Infection of Gammarus duebeni populations by two vertically transmitted microsporidia; parasite detection and discrimination by PCR-RFLP. - Parasitology 125: 59-63.

Hurst G.D.D., Schulenburg H.G., Majerus T.M.O., Bertrand D., Zakharov I.A., Baungaard J., VölKL W., Stouthamer R. \& MaJerus M.E. 1999: Invasion of one insect species, Adalia bipunctata, by two different male-killing bacteria. - Insect Mol. Biol. 8: 133-139.

Mateo Leach I., Hesselingt A., Huibers W.H.C., Witsenboer H., BeuKeboom L.W. \& van de Zande L. 2009: Transcriptome and proteome analysis of ovaries of arrhenotokous and thelytokous Venturia canescens. - Insect Mol. Biol. 18: 477-482.

Mateo Leach I., Ferber S., van de Zande L. \& Beukeboom L. 2012: Genetic variability of arrhenotokous and thelytokous Venturia canescens (Hymenoptera). - Genetica 140: 53-63.

Maynard-Smith J. 1978: The Evolution of Sex. Cambridge University Press, Cambridge, $236 \mathrm{pp}$.

O’Neill S.L., Giordano R., Colbert A.M., Karr T.L. \& RobERTSON H.M. 1992: 16S rRNA phylogenetic analysis of the bacterial endosymbionts associated with cytoplasmic incompatibility in insects. PNAS 89: 2699-2702.

Отто S.P. 2009: The evolutionary enigma of sex. - Am. Nat. 174: S1-S14.

Pelosse P., Bernstein C. \& Desouhant E. 2007: Differential energy allocation as an adaptation to different habitats in the parasitic wasp Venturia canescens. - Evol. Ecol. 21: 669-685.

Pelosse P., Amat I., Bernstein C. \& Desouhant E. 2010: The dynamics of energy allocation in adult arrhenotokous and thelytokous Venturia canescens. - Entomol. Exp. Appl. 135: $68-76$

Reysenbach A.L., Wickham G.S. \& Pace N.R. 1994: Phylogenetic analysis of the hyperthermophilic pink filament community in Octopus Spring, Yellowstone National Park. - Appl. Environ. Microbiol. 60: 2113-2119.

SANDROCK C. \& Vorburger C. 2011: Single-locus recessive inheritance of asexual reproduction in a parasitoid wasp. Curr. Biol. 21: 433-437.

SARIDAKI A. \& Bourtzis K. 2010: Wolbachia: more than just a bug in insects genitals. - Curr. Opin. Microbiol. 13: 67-72.

Schneider M.V., Beukeboom L.W., Driessen G., Lapchin L., Bernstein C. \& Van Alphen J.J.M. 2002: Geographical distribution and genetic relatedness of sympatrical thelytokous and arrhenotokous populations of the parasitoid Venturia canescens (Hymenoptera). - J. Evol. Biol. 15: 191-200.

Schneider M.V., Driessen G., Beukeboom L.W., Boll R., van Eunen K., Selzner A., Talsma J. \& Lapchin L. 2003: Gene flow between arrhenotokous and thelytokous populations of Venturia canescens (Hymenoptera). - Heredity 90: 260-267. 
STEARNS S.C. 1990: The evolutionary maintenance of sexual reproduction: the solutions proposed for a longstanding problem. - J. Genet. 69: 1-10.

Stouthamer R. \& Kazmer D.J. 1994: Cytogenetics of microbeassociated parthenogenesis and its consequences for gene flow in Trichogramma wasps. - Heredity 73: 317-327.

Stouthamer R., Luck R.F. \& Hamilton W.D. 1990: Antibiotics cause parthenogenetic Trichogramma (Hymenoptera: Trichogrammatidae) to revert to sex. - PNAS 87: 2424-2427.

Stouthamer R., van Tilborg M., de Jong J.H., Nunney L. \& LuCK R.F. 2001: Selfish element maintains sex in natural populations of a parasitoid wasp. - Proc. R. Soc. Lond. (B) 268: $617-622$.

SuzuKi M.T. \& Giovannoni S.J. 1996: Bias caused by template annealing in the amplification of mixtures of $16 \mathrm{~S}$ rRNA genes by PCR. - Appl. Environ. Microbiol. 62: 625-630.

Thao M.L.L. \& Baumann P. 2004: Evidence for multiple acquisition of Arsenophonus by whitefly species (Sternorrhyncha: Aleyrodidae). - Curr. Microbiol. 48: 140-144.

Theopold U., Krause E. \& Schmidt O. 1994: Cloning of a VLPprotein coding gene from a parasitoid wasp Venturia canescens. - Arch. Insect Biochem. Physiol. 26: 137-145.

Thiel A., Driessen G. \& Hoffmeister T.S. 2006: Different habitats, different habits? Response to foraging information in the parasitic wasp Venturia canescens. - Behav. Ecol. Sociobiol. 59: $614-623$.

Tobler M. \& Schlupp I. 2010: Differential susceptibility to food stress in neonates of sexual and asexual mollies (Poecilia, Poeciliidae). — Evol. Ecol. 24: 39-47.
Turelli M. \& Hoffmann A.A. 1995: Cytoplasmic incompatibility in Drosophila simulans: Dynamics and parameters estimates from natural populations. - Genetics 140: 1319-1338.

Weiss L.M. \& Vossbrinck C.R. 1998: Microsporidiosis: Molecular and diagnostic aspects. - Adv. Parasitol. 40: 351-396.

Weiss L.M., Zhu X., Cali A., Tanowitz H.B. \& Wittner M. 1994: Utility of microsporidian ribosomal-RNA in diagnosis and phylogeny - A review. - Folia Parasitol. 41: 81-90.

WERREN J.H. \& WindSOR D.M. 2000: Wolbachia infection frequencies in insects: Evidence of a global equilibrium? Proc. R. Soc. Lond. (B) 267: 1277-1285.

WerRen J.H., Zhang W. \& Guo L.R. 1995: Evolution and phylogeny of Wolbachia: Reproductive parasites of arthropods. - Proc. Biol. Sci. 261: 55-63.

WerRen J.H., BALdo L. \& Clark M.E. 2008: Wolbachia: master manipulators of invertebrate biology. - Nat. Rev. Microbiol. 6: 741-751.

Zchori-Fein E. \& Perlman S.J. 2004: Distribution of the bacterial symbiont Cardinium in arthropods. - Mol. Ecol. 13: 2009-2016.

Zchori-Fein E., Gottlieb Y., Kelly S.E., Brtown J.K., Wilson J.M., KarR T.L. \& HunTer M.S. 2001: A newly discovered bacterium associated with parthenogenesis and a change in host selection behavior in parasitoid wasps. - Proc. Natl. Acad. Sci. USA 98: 12555-12560.

Received September 14, 2011; revised and accepted June 28, 2012 